\title{
PARTISIPASI MASYARAKAT DALAM KEBIJAKAN ANGGARAN DAERAH
}

\author{
I Wayan Sutrisna \\ Fakultas Ilmu Sosial dan Ilmu Politik Universitas Mahendradatta Denpasar \\ e-mail : sutrisna76@yahoo.co.id
}

\begin{abstract}
Abstrak - Kebijakan anggaran yang dibuat oleh pemerintah pada prinsipnya bertujuan untuk memenuhi keinginan seluruh lapisan masyarakat. Proses dan pengalokasian anggaran haruslah berorientasi kepada kepentingan publik. Hal ini mengandung arti bahwa proses penyusunan anggaran hendaknya melibatkan banyak pihak mulai dari perencanaan hingga pelaksanaannya. Untuk itu diharapkan belanja untuk kepentingan publik mendapat proporsi yang lebih besar daripada belanja untuk aparatur, karena belanja publik merupakan investasi pemerintah yang diharapkan dapat meningkatkan kesejahteraan masyarakat.

Partisipasi dari seluruh masyarakat dalam politik anggaran daerah sangat diperlukan agar anggaran daerah dapat dipergunakan secara maksimal untuk pembangunan seluruh masyarakat yang ada di daerah tersebut. Mewujudkan partisipasi ini bukanlah hal yang mudah karena masih banyak anggota masyarakat yang masih menganggap penyusunan anggaran daerah hanya ditentukan oleh para petinggi partai penguasa. Program-program masyarakat yang diusulkan dalam Musyawarah Perencanaan Pembangunan (Musrenbang) di tingkat desa kadang akan menghilang di tingkat selanjutnya karena tidak dikawal oleh petinggi partai penguasa. Anggapan ini masih berkembang dimasyarakat sehingga keinginan untuk berpartisipasi dalam politik anggaran daerah menjadi menurun. Anggapan inilah yang harus dihilangkan ditengah masyarakat oleh seluruh komponen pemerintahan sehingga masyarakat mau melibatkan diri dalam setiap proses penyusunan kebijakan anggaran daerah.

Masyarakat yang partisipatif sangat dibutuhkan dalam proses pemerintahan dan pembangunan. United Nation Develepment Program (UNDP) sebuah lembaga dibawah naungan Perserikatan Bangsa-Bangsa yang mengurusi tentang pembangunan bangsa-bangsa di dunia bahkan telah memasukkan partisipasi masyarakat dalam salah satu indicator atau karakteristik pemerintahan yang baik (Good Governance). Hal ini mengandung arti bahwa semakin tinggi tingkat partisipasi masyarakat dalam proses pemerintahan dan pembangunan menunjukkan bahwa pemerintahan yang berkuasa telah melaksankan proses pemerintahan yang baik.

Pengelolaan anggaran daerah dengan melibatkan partisipasi yang tinggi dari masyarakat akan mampu membuat segala perencanaan yang dibuat dalam menyusun anggaran daerah dapat tercapai secara efektif dan efisien. Selain itu kebijakan anggaran partisipatif akan mampu membuat semua program yang dilaksanakan dapat dinikmani oleh seluruh lapisan masyarakat karena seluruh masyarakat merasa telah dilibatkan dalam seluruh prosesnya. Keberhasilan pelaksanaan pembangunan di daerah akan bermuara pada keberhasilan pembangunan secara nasional
\end{abstract}

Kata Kunci: Partisispasi Masyarakat, Kebijakan Publik dan Anggaran.

Abstract - The budget policy made by the government in principle aims to fulfill the wishes of all levels of society. Budget processes and allocations must be oriented to the public interest. This implies that the budget preparation process should involve many parties ranging from planning to implementation. For this reason, it is expected that spending for the public interest gets a greater proportion than spending on the apparatus, because public spending is a government investment that is expected to improve people's welfare. Participation of all people in regional budget politics is very necessary so that the regional budget can be used optimally for the development of all the communities in the area. Realizing this participation is not an easy thing because there are still many members of the community who still consider the preparation of regional budgets only determined 
by officials of the ruling party. The community programs proposed in the Development Planning Consultation (Musrenbang) at the village level will sometimes disappear at the next level because they are not escorted by officials of the ruling party. This assumption is still developing in the community so that the desire to participate in regional budget politics has decreased. This assumption must be eliminated in the midst of the community by all components of the government so that the people want to involve themselves in every process of the formulation of regional budget policies.

Participatory of communities are needed in the process of governance and development. The United Nation Development Program (UNDP), an institution under the auspices of the United Nations which deals with the development of nations in the world, has even included community participation in one of the indicators or characteristics of good governance. This implies that the higher level of community participation in the governance and development process shows that the ruling government has carried out a good governance process.

The management of the regional budget by involving high participation from the community will be able to make all the planning made in preparing the regional budget can be achieved effectively and efficiently. In addition, participatory budget policy will be able to make all programs implemented can be manipulated by all levels of society because all communities feel they have been involved in the entire process. The successful implementation of development in the region will lead to national development success

Keywords: community participation, public policy and budget.

\section{A. Pengantar}

Kebijakan Desentralisasi yang merupakan salah kebijakan penting diera reformasi bertujuan untuk melaksanakan pembangunan secara merata di seluruh wilayah Indonesia. Dengan pemberlakuan kebijakan ini diharapkan menjadi motivasi kepada seluruh komponen masyarakat di daerah untuk ikut serta berpartisipasi dalam seluruh proses pembangunan yang dilaksanakan. Otonomi daerah yang secara efektif dilaksankanan mulai awal tahun 2001 telah mengubah basis pendekatan pengelolaan pemerintahan dan pembangunan di Indonesia dari yang bersifat topdown menjadi bersifat bottom-up. Pemberian hak otonomi kepada daerah bermakna bahwa Pemerintah Pusat menyerahkan wewenang seluas luasnya kepada Pemerintah Daerah untuk mengatur dan mengurus pemerintahannya di luar enam urusan yang masih diatur oleh pemerintah pusat yakni : Politik luar negeri, Pertahanan, Keamanan, Yustisi, Moneter serta fiskal nasional, dan Agama.

Hak otonomi memberikan kesempatan kepada pemerintah daerah dapat mengembangkan segala potensi yang dimiliki untuk sebesar besarnya kemakmuran rakyat. Salah satu tolok ukur keberhasilan daerah dalam pelaksanaan Otonomi Daerah adalah keberhasilan daerah dalam menggali, men- gelola, mengarahkan dan mengendalikan Anggaran Pendapatan dan Belanja Daerah (APBD) sesuai dengan arah kebijakan serta prioritas yang ditetapkan. Dengan belanja pemerintah dalam APBD tiap tahun yang diarahkan ke berbagi bidang pembangunan, program dan kegiatan sesuai dengan prioritas yang ditetapkan oleh daerah diharapkan mampu menstimulan perkembangan pembangunan di berbagai sektor. Sementara itu belanja rutin/aparatur/tidak langsung yang sebagian besar dialokasikan untuk gaji dan upah pegawai serta biaya operasional dan pemeliharaan yang pada dasarnya diharapkan dapat meningkatkan pelayanan terhadap publik/masyarakat.

Berbagai pembelanjaan pemerintah yang sebagian besar dibiayai oleh pendapatan bersumber dari pajak yang digunakan untuk kepentingan masyarakat. Pemerintah membeli barang konsumsi seperti alat-alat perkantoran, pembiayaan gaji dan pembiayaan jasa maupun barang modal seperti bangunan sekolah, perkantoran dan pembangunan infrastruktur. (Sukirno, 2000).

Tujuan utama dari rencana keuangan daerah adalah untuk membantu menentukan tingkat kebutuhan masyarakat terhadap pelayanan sosial dasar seperti kesehatan, pendidikan, listrik, air bersih, transportasi, pemukiman dan pengelolaan sumber daya alam, agar semua kebutuhan masyarakat 
dapat terpenuhi. Permasalahan APBD menjadi sangat penting dalam pembenahan penyelenggaraan pemerintahan daerah karena APBD sebagai indikator terbesar yang dijadikan ukuran oleh masyarakat (stakeholders) untuk melihat apakah ada keberpihakan dari Pemerintah Daerah kepada masyarakatnya. (Purba, 2007)

Sebagai salah satu komponen pertanggungjawaban kepada publik, Pemerintah Daerah diharapkan dapat melakukan optimalisasi belanja yang dilakukan secara efektif dan efisien untuk mencapai tingkat kesejahteraan masyarakat yang lebih baik. Pemerintah pada hakikatnya mengemban tiga fungsi utama, yakni pertama fungsi alokasi, di mana pemerintah mengalokasikan dana sumber-sumber ekonomi dalam bentuk barang dan atau jasa pelayanan masyarakat. Fungsi kedua yaitu fungsi distribusi, yakni fungsi pemerintah dalam usaha untuk melaksanakan pemerataan pembangunan, pendapatan dan kekayaan, agar mengurangi tingkat kesenjangan yang terjadi dalam masyarakat. Fungsi yang ketiga yakni fungsi stabilisasi, yaitu fungsi pemerintah yang meliputi pertahanan keamanan, ekonomi dan moneter agar terpelihara kesempatan kerja yang luas, kestabilan harga dan pertumbuhan ekonomi yang memadai.

Pengalokasian anggaran belanja oleh Pemerintah Daerah diharapkan dapat dilakukan secara hemat berdaya guna dan tepat guna. Peran aktif masyarakat diperlukan dalam proses penyusunan APBD, hal ini dilakukan agar arah kebijakan dalam APBD yang dijalankan benar-benar dapat mengarah kepada kepentingan masyarakat. Selama ini proses penyusunan APBD terkesan hanya melibatkan kaum elit dalam masyarakat saja, sedangkan masyarakat secara luas belum dilibatkan secara optimal, sehingga proses pembangunan yang ditujukan untuk masyarakat sering kali berakhir menjadi proyek mubazir. Selain itu alokasi dana untuk pembangunan saat ini terkesan terlalu besar peranan politisnya sehingga pembangunan hanya menguntungkan kelompok-kelompok tertentu saja.

Perencanaan belanja oleh pemerintah pada prinsipnya bertujuan untuk memenuhi keinginan seluruh lapisan masyarakat. Proses dan pengalokasian anggaran haruslah berorientasi kepada kepentingan publik. Hal ini mengandung arti bahwa proses penyusunan anggaran hendaknya melibatkan banyak pihak mulai dari perencanaan hingga pelaksanaannya. Untuk itu diharapkan belanja untuk kepentingan publik mendapat proporsi yang lebih besar daripada belanja untuk aparatur, karena belanja publik merupakan investasi pemerintah yang diharapkan dapat meningkatkan kesejahteraan masyarakat.

Partisipasi dari seluruh masyarakat dalam politik anggaran daerah sangat diperlukan agar anggaran daerah dapat dipergunakan secara maksimal untuk pembangunan seluruh masyarakat yang ada di daerah tersebut. Mewujudkan partisipasi ini bukanlah hal yang mudah karena masih banyak anggota masyarakat yang masih menganggap penyusunan anggaran daerah hanya ditentukan oleh para petinggi partai penguasa. Program-program masyarakat yang diusulkan dalam Musyawarah Perencanaan Pembangunan (Musrenbang) di tingkat desa kadang akan menghilang di tingkat selanjutnya karena tidak dikawal oleh petinggi partai penguasa. Anggapan ini masih berkembang dimasyarakat sehingga keinginan untuk berpartisipasi dalam politik anggaran daerah menjadi menurun. Anggapan inilah yang harus dihilangkan ditengah masyarakat oleh seluruh komponen pemerintahan sehingga masyarakat mau melibatkan diri dalam setiap proses penyusunan kebijakan anggaran daerah.

\section{B. Mendorong Partisipasi Masyarakat dalam Penyusunan Anggaran Daer- ah \\ Undang-Undang Dasar Negara Repub-} lik Indonesia Tahun 1945 di pasal 1 ayat 2 menyebutkan bahwa Kedaulatan berada di tangan rakyat dan dilaksanakan menurut Undang-Undang Dasar. Hal ini senyuratkan bahwa pemegang kekuasaan tertinggi adalah rakyat sebagai pemilik sah negeri ini. Pada pasal 27 ayat 1 disebutkan bahwa segala warganegara bersamaan kedudukannya di dalam hukum dan pemerintahan dan wajib menjunjung hukum dan pemerintahan itu dengan tidak ada kecualinya. Segala proses dalam pelaksanaan kehidupan berbangsa dan bernegara harus melibatkan masyarakat sehingga ujung dari semua pelaksanaan kehidupan bernegara adalah meningkatnya kesejahteraan seluruh rakyat. Masyarakat yang partisipatif akan mampu menghasilkan proses pembangu- 
nan yang berkualitas dan tepat sasaran.

Meskipun partisipasi masyarakat sudah dijamin oleh undang-undang, namun dalam pelaksanaannya masih belum maksimal seperti apa yang diharapkan dalam peraturan perundang-undangan. Hal ini bisa diakibatkan oleh beberapa hal seperti tidak adanya kemauan yang kuat dari pemerintah daerah dalam melibatkan seluruh masyarakat untuk ikut berpartisipasi dalam setiap proses pembangunan yang dilaksanakan. Selain itu juga diakibatkan oleh kesadaran masyarakat yang masih kurang untuk ikut berpartisipasi dalam proses pembangunan itu sendiri. Kondisi-kondisi seperti inilah yang mengakibatkan proses pembangunan terutama dalam hal kebijakan anggaran daerah menjadi minim keterlibatan masyarakat.

Dalam penyusunan kebijakan anggaran daerah undang-undang telah menjamin prosesnya bersifat bottom-up, yakni mulai dari tingkat desa berupa musyawarah perencanaan pembangunan (musrenbang) desa dilanjutkan dengan tingkat kecamatan, tingkat kabupeten, kemudian diteruskan pada tingkat provinsi hingga pada pemerintah pusat. Proses ini mulai dari tingkat musrenbangdes di tingkat desa secara aturan harus melibatkan masyarakat sebagai subyek dan obyek dari pembangunan. Namun pada kenyataannya masyarakat yang terlibat hanya sebagian kecil yakni para elit desa dan para pengurus partai yang berkuasa. Selain itu program-program yang sudah diusulkan dari tingkat desa kadang harus terhalang oleh program-program yang telah disusun oleh pemerintahan itu sendiri, baik karena keterbatasan anggaran yang tersedia maupun faktor lainnya.

Hosnan (2007) mengemukakan bahwa belum terakomodirnya partisipasi masyarakat dalam proses politik anggaran daerah disebabkan beberapa hal yakni :

1. Belum adanya komitmen yang baik (good will) dari pemerintah daerah guna melibatkan masyarakat secara maksimal dalam proses kebijakan anggaran.

2. Program pembangunan yang terakomodir dalam kebijakan anggran seringkali tidak didasari oleh kepentingan dan kebutuhan publik.

3. Masyarakat (terutama di daerah pedesaan) juga belum mampu berpartisipasi secara maksimal karena keterbatasan sumber daya yang ada. Mereka sebagian besar berada dalam kondisi pengethuan dan pemahaman yang minim tentang partisipasi masyarakat dalam pembangunan daerah. Sehingga mereka seringkali hanya diekspolitasi keberadaannya untuk mendukung kegiatan pembangunan yang sudah ditetapkan oleh pemerintah. Bahkan terkadang pelibatan masyarakat hanya untuk memenuhi ketentuan peraturan perundang-undangan yang berlaku, sedangkan keinginan dan kebutuhan mereka tidak didengar apalagi dipenuhi.

Pelibatan masyarakat dalam kebijakan anggaran daerah sangat penting dalam rangka mewujudkan program-program yang tepat sasaran dan berorientasi pada kepentingan masyarakat secara umum. Darmawan Purba (2007) menyebutkan bahwa terdapat beberapa hal yang berkaitan dengan pelibatan masyarakat dalam penyusunan kebijakan anggaran daerah yakni :

1. Kebijakan anggaran yang meliputi perencanaan, penyusunan, pelaksanaan dan pengawasan mutlak dilaksanakan dengan melibatkan masyarakat dalam rangka menjamin hak masyarakat serta mewujudkan kesejahteraan dan keadilan sosial.

2. Dalam rangka mewujudkan penyelenggaraan pemerintahan yang baik, maka kebijakan anggran daerah perlu melibatkan masyarakat dengan pendekatan community driven planning dengan harapan :

a) Terciptanya kesepakatan dan kebersamaan di masyarakat dalam rangka mewujudkan keadilan sosial karena kebijakan anggaran disusun berdasarkan aspirasi masyarakat secara bersama-sama.

b) Meningkatnya rasa memiliki masyarakat terhadap program-program pemerintah yang sejalan dengan terakomodasinya aspirasi masyarakat dalam program yang akan dilaksanakan.

c) Mewujudkan masyarakat mandiri yang dapat memenuhi dan mengupayakan pemenuhan kebutuhan sendiri seiring dengan proses pembelajaran berpartisipasi yang terkandung dalam pendekatan peran serta masyarakat dalam kebijakan 
anggran daerah.

d) Meningkatkan legitimasi program-program pembangunan daerah karena disepakati secara bersama-sama yang pada akhirnya dapat mewujudkan pembangunan yang berkelanjutan.

3. Dengan meningkatnya peran serta masyarakat dalam proses kebijakan anggaran maka good governance dapat terwujud yang pada akhirnya semakin meningkatkan efisiensi dan efektivitas pembangunan daerah. Hal ini terjadi karena penyelenggaraan pembangunan akan lebih bisa dilakukan secara transparan, akuntabel, bermoral dan beretika yang berorientasi pada rakyat.

Partisipasi masyarakat dalam kebijakan anggaran daerah harus terus ditumbuhkan oleh semua komponen yang terlibat dalam pemerintahan. Kebijakan anggaran yang partisipatif merupakan cermin dari baiknya pengelolaan pemerintahan yang dilaksanakan oleh para pemimpin yang berkuasa. Anggaran yang rancang, disusun, dilaksanakan dan diawasi oleh masyarakat akan menghasilkan program-program yang mampu memecahkan berbagai permasalahan yang dihadapi oleh masyarakat. Kebijakan anggaran yang didukung oleh partisipasi masyarakat akan mampu menghasilkan pembangunan yang tepat guna dan berdaya guna sehingga tujuan dari pembangunan yang dilaksanakan dapat dinikmati oleh seluruh masyarakat yang bermuara pada peningkatan kesejahteraan masyarakat.

\section{Kebijakan Anggaran Partisipatif wujud pelaksanaan "Good Gover- nance"}

Keterlibatan masyarakat dalam proses pembangunan di Indonesia pada umumnya saat ini masih sangat rendah. Rendahnya partisipasi ini akibat dari kebijakan pemerintah yang masih kurang dalam memberikan ruang bagi setiap warga Negara untuk berpartisipasi dalam pembangunan. Pelaksanaan Musyawarah perencanaan Pembangunan (Musrenbang) mulai pada tingkat desa hingga nasional dianggap oleh sebagaian masyarakat hanya proses serimonial belaka. Musrenbang yang dilaksanakan selama ini hanya melibatkan segelintir elit dalam masyarakat saja dan tidak member- ikan ruang yang cukup kepada mayoritas masyarakat.

Masyarakat yang partisipatif sangat dibutuhkan dalam proses pemerintahan dan pembangunan. United Nation Develepment Program (UNDP) sebuah lembaga dibawah naungan Perserikatan Bangsa-Bangsa yang mengurusi tentang pembangunan bangsa-bangsa di dunia bahkan telah memasukkan partisipasi masyarakat dalam salah satu indicator atau karakteristik pemerintahan yang baik (Good Governance). Hal ini mengandung arti bahwa semakin tinggi tingkat partisipasi masyarakat dalam proses pemerintahan dan pembangunan menunjukkan bahwa pemerintahan yang berkuasa telah melaksankan proses pemerintahan yang baik.

United Nation Develepment Program (UNDP) memberikan 9 katakteristik dalam mewujudkan tata kelola pemerintahan yang baik (Good Governance). Karakteristi-karakteristik tersebut yakni:

\section{Partisipasi (Participation)}

Sebagai pemilik kedaulatan, setiap warga negara mempunyai hak dan kewajiban untuk ambil bagian dalam kehidupan berbangsa dan bernegara. Partisipasi dapat dilakukan secara langsung atau melalui perwakilan. Partisipasi dilakukan secara menyeluruh mulai dari penyusunan kebijakan, pelaksanaan, evaluasi hingga pemanfaataan hasil-hasilnya. Tingkat partisipasi masyarakat akan sangat menentukan keberhasilan kebijakan yang diterapkan.

\section{Penegakan hukum (rule of law)}

Tanpa penegakan hukum tidak akan tercipta kehidupan yang demokratsis melainkan anarkis. Tanpa penegakan hukum orang akan secara bebas mencapai tujuannya sendiri tanpa mengindahkan kepentingan orang lain, termasuk menghalalkan segala cara. Oleh karena itu langkah awal mewujudkan good Governance adalah membangun sistem hukum yang baik dan sehat.

\section{Transparansi (transparancy)}

Karakteristik ini sesuai dengan semangat jaman yang serba terbuka akibat adanya revolusi informasi. Keterbukaan tersebut mencakup semua aspek aktivitas yang menyangkut kepentingan publik mulai dari pengambilan keputusan, penggunaan dana-dana publik sampai pada tahap evalua- 
si.

\section{Daya tanggap (responsivencess)}

Sebagai konsekwensi logis dari keterbukaan maka setiap komponen yang terlibat dalam pembangunan good governance perlu memiliki daya tanggap terhadap keinginan maupun keluhan para stakeholders.

5. Berorientasi pada konsensus (consensus orientation)

Dalam pelaksanaan prinsip good governance, pengambilan keputusan maupun pemecahan masalah bersama lebih diutamakan berdasarkan konsensus, yang dilanjutkan dengan kesediaan untuk konsisten melaksanakan konsensus yang telah diputuskan bersama.

\section{Keadilan/kesetaraan (equity)}

Setiap warganegara memiliki hak yang sama untuk memperoleh kesejahteraan. Akan tetapi karena kemampuan masing-masing warga negara berbeda, maka pemerintah perlu memainkan peran untuk memberikan keadilan dalam kesejahteraan seluruh masyarakat.

7. Keefektivan dan efisiensi (effectiveness and efficiency)

Agar mampu berkompetisi secara sehat dalam percaturan dunia perlu mengutamakan efektivitas dan efisiensi dalam setiap kegiatan. Tanpa adanya kompetisi tidak akan tercapai efisiensi.

\section{Akuntabilitas (accountability)}

Setiap aktivitas yang berkaitan dengan kepentingan publik perlu mempertanggungjawabkan kepada publik. Tangggung jawab tidak hanya diberikan kepada atasan saja melainkan juga kepada stakeholders atau masyarakat luas.

9. Visi strategis (strategic vision)

Di era yang berubah secara dinamis seperti sekararang ini setiap sektor dalam good governance perlu memiliki visi yang strategis. Tanpa adanya visi ini maka suatu bangsa dan negara akan mengalami ketertinggalan. Visi perlu dibedakan antara visi jangka panjang 20-25 th, serta jangka pendek sekitar 5 tahun.

Dengan dimasukkanya partisipasi masyarakat sebagai salah satu karakteristik utama dalam mewujudkan tata pengelolaan pemerintahan yang baik mengharuskan setiap pemerintahan baik pusat maupun daerah mestinya selalu berusaha meningkatkan partisipasi masyarakat dalam proses pembangunan. Dalam konteks kebijakan anggaran daerah, partisipasi masyarakat merupakan suatu keharusan karena anggaran yang disusun untuk pelaksanaan pembangunan di daerah harus merupakan hasil kesepakatan antara pemerintah dengan masyarakat. Meskipun secara aturan anggaran daerah disusun oleh legeslatif dan eksekutif daerah, namun sebelum anggaran itu disusun dan disahkan sebaiknnya proses tersebut melibatkan masyarakat secara luas.

Kebijakan anggaran yang partisipatif akan mampu mewujudkan tata kelola pemerintahan yang baik karena seluruh proses penyusunan, pelaksanaan dan pengawasan juga dilakukan oleh seluruh lapisan masyarakat. Untuk mewujudkan hal tersebut memang masih berat, namun dengan kemauan yang kuat dari para penguasa hal tersebut pasti dapat terwujud. Masyarakat akan bersedia melibatkan diri dalam proses ini apabila pemerintah memberikan kesempatan dan keyakinan bahwa seluruh masyarakat harus ikut serta dalam setiap proses pembangunan.

\section{Mewujudkan Pembangunan Nasi- onal dengan memperkuat pemban- gunan Daerah}

Pembangunan Nasional yang dilaksanakan di Negara Kesatuan Republik Indonesia adalah untuk mewujudkan Tujuan nasional seperti yang termuat dalam pembukaaan Undang-Undang dasar 1945 alinia IV yaitu melindungi segenap bangsa Indonesia dan seluruh tumpah darah Indonesia dan untuk memajukan kesejahteraan umum, mencerdaskan kehidupan bangsa, dan ikut melaksanakan ketertiban dunia yang berdasarkan kemerdekaan, perdamaian abadi dan keadilan sosial. Pembangunan Nasional merupakan usaha untuk meningkatkan seluruh aspek kehidupan masyarakat, bangsa dan negara yang sekaligus merupakan proses pengembangan dan pemberdayaan seluruh komponen dalam kehidupan bernegara guna mewujudkan tujuan nasional.

Hakikat dari Pembangunan nasional adalah pembanguan yang dilaksanakan secara merata untuk seluruh masyarakat dan wilayah Indonesia. Pembangunan dilaksanakan bersama oleh masyarakat dan pe- 
merintah. Masyarakat adalah pelaku utama pembangunan dan pemerintah berkewajiban mengarahkan, membimbing serta menciptakan suasana yang menunjang kelancaran proses pembangunan. Kegiatan masyarakat dan pemerintah harus saling mendukung, saling mengisi dan saling melengkapi dalam satu kesatuan gerak menuju tercapainya satu tujuan yakni tujuan pembangunan nasional.

Dalam mewujudkan tujuan pembangunan nasional setiap pemimpin pemerintahan selalu berusaha membuat program-program unggulan yang akan dilaksanakan agar pencapaian kesejahteraan masyarakat sebagai tujuan utama dapat terwujud. Seperti program prioritas yang dicanangkan oleh pemerintahan Presiden Jokowi adalah Nawa cita. Program Nawa Cita berisi 9 program prioritas yang akan diwujudkan selama pemerintahan ini diberikan mandat oleh rakyat dalam mengelola negara.

Salah satu program prioritas dalam Nawa Cita dari Presiden Jokowi adalah membangun Indonesia dari pinggiran dengan memperkuat daerah-daerah dan desa dalam kerangka negara kesatuan. Membangun Indonesia dari daerah sudah dilaksanakan sejak pemerintah pusat memberikan hak otonomi kepada pemerintah daerah dalam hal ini adalah pemerintah kabupaten dan kota. Pemberian hak otonomi ini agar pemerintah daerah mampu melaksanakan pembangunan sesuai dengan kebutuhan masyarakat di daerah masing-masing. Hal ini dilakukan agar pemerataan pembangunan dapat dilaksanakan lebih cepat dan terarah.

Membangun Indonesia dari daerah merupakan cita-cita bangsa Indonesia sejak awal kemerdekaan, namun penerapan secara nyata baru dapat dilaksanakan pada era reformasi dengan dikeluarkannya undang-undang otonomi daerah yang dilaksankan secara efektif sejak tahun 2001. Pemerintah pusat memberikan keleluasaan bagi pemerintah daerah otonom untuk mengembangkan daerahnya dengan pengerahan segala potensi yang dimiliki serta didukung juga dengan anggaran dari pusat.

Pembangunan yang dilaksanakan pada masing-masing daerah harus disinergikan dengan program pembangunan yang akan dilaksanakan di tingkat pusat. Rencana pembangunan yang akan dilakukan di tingkat daerah otonom tidak boleh menyimpang dari rel rencana pembangunan yang dilaksanakan oleh pusat. Dalam laman Kementerian Dalam Negeri www. kemendagri.go.id disebutkan bahwa sebanyak 3.143 peraturan daerah (Perda) yang diberlakukan di daerah-daerah otonom telah dicabut/direvisi dan dibatalkan oleh pemerintah pusat. Hal ini dilakukan karena perda-perda tersebut dianggap bertentangan dengan kebijakan-kebijakan yang dikeluarkan oleh pemerintah pusat.

Dengan memperkuat pembangunan yang dilaksankan di daerah-daerah akan mengakibatkan percepatan tercapainya tujuan nasional. Pembangunan yang dilaksanakan di daerah yang sudah disingkronisasikan dengan Rencana Pembangunan Nasional akan mampu mewujudkan tercapinya tujuan dari pembangunan nasional. Pengalokasian anggaran langsung ke daerah membuat daerah dapat mewujudkan kesejahteraan masyarakat secara maksimal. Terwujudnya kesejateraan masyarakat di setiap daerah akan dapat mewujudkan kesejahteraan nasional secara menyeluruh. Perwujudan pembangunan nasional dari pinggir/daerah merupakan amanat Undang-Undang Dasar Negara Republik Indonesia Tahun 1945 utamanya pasal 18, 18A, dan 18B.

\section{E. Penutup}

Menumbuhkan partisipasi masyarakat dalam proses pembangunan termasuk dalam proses kebijakan anggaran daerah sampai saat ini masih cukup sulit diwujudkan. Masyarakat masih menganggap proses penyusunan anggaran merupakan dominasi para elit dan pimpinan parpol berkuasa saat ini. Selain itu keinginan baik dari pemerintah yang berkuasa untuk melibatkan masyarakat secara menyeluruh juga masih kurang. Namun usaha untuk menumbuhkan partisipasi masyarakat dalam proses kebijakan anggaran daerah sudah semakin sering digalakkan menuju tata kelola pemerintahan yang baik dimana salah satu indikatornya adalah tingkat partisipasi masyarakat.

Kebijakan anggaran daerah merupakan kebijakan yang akan diterapkan untuk membiayai seluruh kegiatan dan pembangunan yang akan dilaksanakan di daerah. Kebijakan anggaran merupakan komponen pembiayaan pembangunan menuju kese- 
jatraan masyarakat. Otonomi daerah telah memberikan keleluasaan bagi daerah dalam mengelola potensi yang dimiliki dalam pelaksanaan dan penganggaraan keuangan daerah dalam koridor negara kesatuan. Mewujudkan kebijakan anggaran yang partisipatif mutlak harus dilaksanakan oleh seluruh pemerintah daerah yang ada di Indonesia. Partisipasi masyarakat harus terus didorong agar kebijakan anggaran yang disusun dan dilaksanakan mencerminkan kebijakan yang berpihak kepada kepentingan seluruh masyarakat.

Tingkat partisipasi masyarakat untuk ikut terlibat dalam proses kebijakan anggaran daerah menunjukkan tingkat keberhasilan sebuah daerah dalam melaksanakan tata kelola pemerintahan yang baik. Tata kelola pemerintahan yang baik (Good Governance) merupakan tujuan dari seluruh pemerintahan yang ada di dunia karena tata kelola pemerintahan yang baik ini merupakan program dari Perserikatan Bangsa-Bangsa yang di laksanakan oleh United Nation Develepment Program (UNDP). Saat ini seluruh pemerintahan di dunia secara maksimal berlomba-lomba untuk melaksanakan kreteria-kreteria yang diamanatkan dalam pelaksanaan tata kelola pemerintahan yang baik.

Pengelolaan anggaran daerah dengan melibatkan partisipasi yang tinggi dari masyarakat akan mampu membuat segala perencanaan yang dibuat dalam menyusun anggaran daerah dapat tercapai secara efektif dan efisien. Selain itu kebijakan anggaran partisipatif akan mampu membuat semua program yang dilaksanakan dapat dinikmati oleh seluruh lapisan masyarakat karena seluruh masyarakat merasa telah dilibatkan dalam seluruh prosesnya. Keberhasilan pelaksanaan pembangunan di daerah akan bermuara pada keberhasilan pembangunan secara nasional. Membangun Indonesia dari daerah seperti apa yang dicita-citakan oleh pemerintah dan masyarakat saat ini akan mampu terwujud dengan tingkat partisipasi yang tinggi dari seluruh masyarakat.

\section{DAFTAR PUSTAKA}

Arsyad, L. 1999. Pengantar Perencanaan dan Pembangunan Ekonomi Daerah. Yogyakarta. BPFE-UGM.

Dunn, William N. 1990. Analisa Kebijaksanaan Publik. Yogyakarta. Penerbit PT Hanindita.

Dwiyanto, Agus. 2006. Reformasi Birokrasi Publik di Indonesia. Yogyakarta. Gadjah Mada University Press.

Hakim, Lukman. 2011. Pengantar Administrasi Pembangunan. Jogjakarta. Ar-Ruzz Media.

Kaho, J.R. 1997. Prospek otonomi di Negara Republik Indonesia. Jakarta. PT Raja Grafido persada.

Leo Wiratma I Made, Djadijono M, Legowo TA.editors. 2007. Membangun Indonesia Dari Daerah, Partisipasi Publik dan Politik Anggaran Daerah. Jakarta. CSIS.

Mandica, Notrida. 2001. Desentralisasi, Anggaran daerah, dan Akuntabilitas Publik. Jakarta. Kompas, Juni Nomor 338 tahun Ke-36, PT Kompas Media Nusantara.

Siagian. S. P. 1983. Administrasi Pembangunan: Konsep, Dimensi dan Strateginya. Jakarta: PT Gunung Agung.

Sumarto, Sudarno, Asep Suharyadi, Alex Arifianto. 2004. Tata Kelola Pemerintahan dan Penanggulangan Kemiskinan : Bukti-bukti Awal Desentralisasi di Indonesia. Lembaga Penelitian SMERU. Jakarta.

Todaro, Michael P. Dan Stephen C Smith,. 2004. Pembangunan Ekonomi di Dunia Ketiga, edisi kedelapan. Jakarta. Penerbit Erlangga.

Undang-Undang Dasar Republik Indonesia dan Perubahannya, (Amandemen I, II, III dan IV), Penabur Ilmu.

www. kemendagri.go.id 